\title{
Reproliferation of Islamist Movement in Surakarta: Trajectory and Strategy in The Post Democratization Indonesia
}

\author{
Muhammad Abzar Duraesa \\ IAIN Samarinda \\ email:abzariainsmd@gmail.com
}

\section{Muzayyin Ahyar}

IAIN Samarinda

email:muz.ahyar@gmail.com

\begin{abstract}
Islamist movement has been proliferating in line with the historical trajectory of Indonesia's political journey; starting from the colonial regime, in the beginning of independence, New Order regime and today's Era Reformasi. The process of Democratization and modernization lead the ideology of Islamism to a new phase of religious movement. Along with the growth of democracy in Indonesia, Islamist movement precisely shows its existence intensely in public sphere. The opening canals of freedom in the Reformation Era became a new space for ideology of Islamism to evolve and adapt some strategies to survive amidst the onslaught democratization in Indonesia. This article aims at looking to what extent the proliferation of Islamist movements after the collapse of Soeharto's authoritarian regime in Indonesia. In this case, Surakarta becomes important to observe because it's historical context as an embryo in giving birth to earlier Islamist movements, as well as a city famous for the proliferation of ideology of Islamism in Indonesia. Using political sociology approach, this study attempts to understand the path of proliferation of Islamist movements and its various interplayed strategies to the socio-political conditions that occur; either on a global or local scale. This article argues that the development of democracy in Indonesia continues to alter the route map of the Islamist movement. Finally, the results of this study reveal that the proliferation of the current Islamist movement
\end{abstract}


plays a new strategy that appropriated with the development of democracy and technological advancements to gain more public sphere by Indonesian people.

\section{Keywords:}

Islamist movement, democratization in Indonesia, Surakarta, Politic

\section{Introduction}

Since the early history of Indonesia, this country has become the important part in discussing the ideology of Islamism all over the Islamic worlds. Islamism, as popularly explained by some scholars, is often ascociated with the ideology that highlight the universality of Islamic values as the way of life. Nazih Ayubi Argues that Islamism is a concept which birth from the political context; when Muslims response to situation of political disorder by the extremely religious spirit. According to Ayubi, Islamism represents some Muslims spirit for merging the three notions in Islam; din, dunya and daulah. Ayubi then reveals that the output which is coming from the spirit of Islamism by the term political Islam (Ayubi, 2003). The other definition of Islamism by some late scholars that Islamism is a concept and action which purposed to establish the "Islamic State"; the state that it's legitimation based on Islamic normativity (Roy, 1996). In its historical theory, Islamism has the elements related to the actor, ideology and activism. Islamism also needs a common ground to create a new world order based on Islamic values (Kepel, 2006). All movements, groups or activism which carry out Islam as a political ideology (Islamism) have their own strategy in spreading the political Islam. Some movements act extensively and radically by committing acts of violence in order to change socio-political conditions as expected quickly. Several movements follow the stream of legal political contestation appropriated to their country.

From all terminological understandings of Islamism, the common similarity asserts that Islamism is more politically symptom than the DINIKA, Volume 4, Number 2, May - August 2019 
religious tendency. Bassam Tibi strictly reveals that Islamism is not the fundamental teaching of Islam. While Islamism began from the political orders; the truly Islamic teaching was start from the moral teaching (Tibi, 2012). According to all terminological understandings, it is clearly enough that Islamism has existed even since the pre-independence era of Indonesia.

Solo, the other popular name of Surakarta, becomes a considerable attention because the stigma as a city of terrorist; the city which wellknown by its movements, groups and actors of the extreme Islamist, especially after the downfall of New Order regime. Some incidents like Gereja Bethel Injil Sepenub Kepunten Solo bombing (2011), the attacking of pos pengamanan lebaran at Gemblegan (2012), Mapolresta Surakarta bombing (2016) and so forth are seem to confirm the stigma that Solo is a city of Terrorist. In line with the proliferation of Islamism in Indonesia, the analysis of Islamist activism, violence action and the other discourses of Islamism are always focused on the matter of security, intelligence, and national defense. The groups networking, funding, tactics and weapon sources are the main discussed issues in every mainstreaming study.

The proliferation of the Islamist movement in Solo was well explained by several scholars such Muhammad Wildan's work on radical Islamism in Solo. Wildan mapped the Islamis movement in Solo in every political regime of Indonesia. According to Wildan, the proliferation of Islamist movement in Solo is a long process history since the Dutch colonial era, and really not merely regarding on the conduciveness of national politics or national security and defense. The proliferation of Islamist movement could be understood by discussing firstly about the historical account of Islam in Solo. Islam has become the cultural movement since the interaction between Susuhanan Pakubuwana II (1726-1749), the king of the ancient Surakarta, with the Kiai Hasan Besari the leader of Pesantren Gebangtinatar at Tegalsari Ponorogo, east part of Java. 
The further development of Islam was occurred in the era of Pakubuwana IV, who has invited more ulamas from several regions to stay in Solo. One of the famous ulamas is Kyai Jamsari from Banyumas, he has built a mosque on the southwestern side of Surakarta Kingdom. Today, the area around the historical mosque is known as the name Jamsaren village and Pondok Jamsaren. The next period, the development of Islamist movement began to be patterned since the Dutch government formed enclaves for controlling some communities. The designed enclaves divided into three district point; Kauman for the religious employees of the Kingdom (priyayis), Pasar Kliwon for Arabs, and Laweyan for JavaneseMuslim Businessmen (santris), Jebres for Chinese business people. The establishment of these enclaves actually made it easier for some groups to consolidate their political power by forming a social movement that opposed the Dutch government. The famous resistance recorded in history is the Sarekat Dagang Islam (SDI, Islamic Trade Union) movement which wants to fight for the Muslim trader rights in Solo. Islam as a political movement, according to Wildan, continues in the post-independence eras of Indonesia. Wildan mentions some actors and Islamist groups; Jamaah Islamiyah, Ngruki Networks, Front Pemuda Islam Surakarta (FPIS, Muslim Youth Front of Surakarta), Jamaah Gumuk, Laskar Jundullah, Laskar Hizbullah Sunan Bonang, Hawariyyun (The disciples), Brigade Hizbullah, Barisan Bismillah dan Al-Ishlah (Wildan, 2008).

Using the historical approach, Wildan's work has a power in exploration of historical narratives regarding the first emergence of Islam as a social movement and political reaction in Solo. Nevertheless, Wildan has not explained yet how the dynamic of historical account in Solo in the past, played a role in establishing and reemergence of Islamist movement in contemporary Indonesia. This paper will enrich some studies regarding Islamism in Solo. Some questions emerge in this paper to complement the shortcomings of earlier studies on how the dynamic relationship between 
Islamist movement in the past and the contemporary Islamist movement? How the proliferation of Islamist movement in the contemporary political circumstance of Indonesia? How the strategy and trajectory of Islamist movement in facing the dynamic democratization in Indonesia? Would Solo continue to be a city with the proliferation of Islamist movements in the future? Some questions above become the keyword in this paper.

\section{Early Islamist Groups in Surakarta}

The root of Islamist ideology (Islamism) could be traced back since the pre-independence day of Indonesia. In Solo, the spirit to create Islam as the way of life (or Islam kaffah) had shown by Sarekat Dagang Islam (SDI, Islamic Trade Union) one famous movement in the pre-independence era. Sarekat Dagang Islam was initiated by Kyai Haji Samanhudi, the famous Muslim Trader. Initially, SDI was Muslim response to the Dutch government's political trade policy which discriminates between inlander (indigene) and non-inlander (Europeanen and V reemde Oosterling). In 1912, SDI transformed to Sarekat Islam (Islamic Union). Sarekat Islam has a broader scoop of organizational idea; it is not merely about economic condition, but embracing in the socio-political condition. Sarekat Islam becomes a frontline in resisting all policies that deemed to damage Islam (Nasihin, 2012).

Actually, Sarekat Islam was not radical Islamist movement because the situation of Indonesia did not set yet as the independence nation, all prominent figures of political identity who existed in Indonesia (even secular nationalist, religious nationalist, democratic, socialist communist) were in struggle for their victory from the Dutch government. All Indonesian political figures argue that they had to act radically for gaining the sovereign country. Nevertheless, the spirit of political Islam which has desire in "Islamizing the country" becomes the red thread of identity between Islamist movement in the pre-independence day and the contemporary Indonesia. 
The militant Islamist movement has become the part of history over the early years of Indonesia's independence. Basically, the Islamist movement that led by Abdullah Sungkar and Abu Bakar Bakar Ba'asyir in the 1980s is only the successor of the Darul Islam and Negara Islam Indonesia (Islamic State of Indonesia) movement proclaimed by Kartosuwiryo on August 7, 1949 in Cisampak Tasikmalaya (Anshori, Yusuf, \& Zarkasyi, 2008). Abdullah Sungkar is a muballigh (Islamic propagandist) from Hadhrami descent. He was born in Solo 1937, he is one of the initiators of Al-Mukmin Ngruki Islamic Boarding School except his colleague Abu Bakar Ba'asyir in 1972 (Qodir, 2003). Sungkar took up his education at AlIrsyad Solo, and began his organizational experience in Gerakan Pemuda Islam Indonesia (GPII, Indonesian Islamic Youth Movement). Sungkar later became a sympathizer of the Masyumi party (Indonesian Muslim Syuro Assembly) at a relatively young age. Besides, Sungkar idolized Natsir as a Muslim politician who was considered to fight for Islamic law through the Masyumi party that he led (Solahudin, 2011). It seems that from AlIrsyad, Sungkar knew the ideology of salafism, besides his activity in GPII let him fight for establishment of Islamic Sharia in Indonesia by high enthusiasm.

Sungkar began to get along with Ba'asyir when they met in Radio Dakwah Islamiyyah Surakarta (Radis) and pioneering in Pondok Pesantren Ngruki establishment. Just like Sungkar, Ba'asyir is also an Islamic propagandist from Arabic descent. Both of them actively opposed the government of Indonesia when they gathered in Darul Islam (DI). Sungkar and Ba'asyir invite about 12 ulama around Solo to join them for founding the "jama'ah" to campaign the Islamic sharia in Indonesia. Some Solo Islamic figures among these 12 persons are Abdullah Marzuki - the founder of Pondok Pesantren Assalam Solo - and Abdullah Thuffail Saputra - The founder of Majelis Tafsir al-Quran, one of famous Islamic mass organizations in Solo. Most of ulama who invited by Sungkar and 
Ba'asyir reject softly the campaign of the establishment of Islamic sharia in Indonesia. Sungkar and Ba'asyir always use the atsar (saying of Prophet Muhammad's closes friends) from Umar ibn Khattab "la islama illa bi al jama'ah, wa la jama'ata illa bi al imarah, wa la imarata illa bi al itha'ab" (there is no Islam for anyone if he does not participate in jama'ah, and would not considered to be jama'ah except by the leadership, and there is no leadership except by the observance to Allah) (Solahudin, 2011).

In the late 1970s till 1980s is a significant time for Sungkar and Ba'asyir for power consolidating around Solo because in that years they were the prominent leaders of DI around Surakarta. Sungkar were the candidate of Imam (spiritual leader) of DI as a successor of Adah Jailani, the definitive leader of DI, who arrested as a political prisoner of New Order. He is nominated by the Majelis Syuro of DI in 1987 together with two prominent figures; Abdul Farah Wirananggapati, the first commander of DI in West Java, and Ajengan Masduki. Unfurtonately, Sungkar was not in a popular candidate around their members of DI. Most of the members agreed that Ajengan Masduki is most suitable choice, at least in a caretaker capacity. Once chosen acting Imam, Masduki put his own men in key positions, including Abdullah Sungkar as responsible for foreign affairs, in particular seeking funding and political support from Islamist abroad, and Abu Bakar Ba'asyir as minister of justice. In his first effort, Sungkar focused on raising funds from Saudi Arabia and Rabithah, besides, Sungkar also in position to make clear the recruitment of combatants to Afghanistan (International Crisis Group (ICG), 2005).

Sungkar and Ba'asyir still close together, even the organizational disintegrate in the organization of DI. While Ajengan Masduki still stayed in Darul Islam, Sungkar and Ba'asyir organized themselves in the Jama'ah Islamiyyah. The disintegration of two famous figures in DI was allegedly because Sungkar and Ba'asyir disagreed with the Masduki's theological thought (especially in the concept of Tauhid) which tended to Sufism 
(Abas, 2009). But in the other thesis argues that the disintegration had occurred because the struggle for the position of Amir Darul Islam since a long time ago before 1992. In 1993, Sungkar and Ba'asyir collaborated in founding Jama'ah Islamiyyah (JI) which affiliated to the ideology of salafy jihadis (Anshori et al., 2008). Sungkar and Ba'astir consistently opposed to the New Order regime, moreover when the President Soeharto applied the Pancasila as the asas tunggal (single basic principle) for all national life. They argue that New Order regime is an enemy that has to be fought because this regime was compelled Muslim people to accept the basic principle except the Islamic norms. Soeharto, the leader of the New Order regime deemed to be kafir mahally, Muslim leader who has not govern in the name of Islam, they reject the establishment of Islamic sharia in the country. According to Sungkar and Ba'asyir, kafir mahally is more dangerous than kafir ajnabiy; the non-Muslim who has occupied and declared the war with "Islamic state" like Afghanistan, Palestine and so forth (Solahudin, 2011).

In his position as the leader of Jamaah Islamiyyah, Sungkar also aggressively recruited members from several cities, including Solo, which he controlled from Malaysia. It was not difficult for Sungkar-Ba'asyir to rebuild the organization, because they already had a mass base in Solo. When the political circumstance in Indonesia were in chaos due to the Asian crisis which affected the collapse of the New Order regime, SungkarBa'asyir returned to the country after his escape for approximately 15 years from the neighboring country; Malaysia. They received tremendous good response from their colleagues in Indonesia, especially in Solo. But shortly after his return to the country, Sungkar was died because of the illness he suffered in 1999. Some of Sungkar and Ba'asyir's congregations were ready to return to fight for their Islamic political ideas by gathering many congregations scattered around Solo. Political struggle was continued by Ba'asyir. The realm of democracy also seems advantaged Ba'asyir and his congregations. In the early years of the Era Reformasi, Ba'asyir returned to 
his da'wah activity at several mosques in Solo such as al-Ikhlas mosque and Baitul Amin Cemani, Laweyan mosque, and Marwa Semanggi mosque. After the 2002 Bali Bombing incident, Ba'asyir was arrested on suspect of having networks with the trans-national Islamist movement in Egypt and Afghanistan, he also allegedly has affiliated with Al-Qaeda.

\section{Islamist Groups in The First Decade of Democratization}

The fall down of the President Soeharto from political power has brought the broad impact in the national politics. The pace of the wave of democratization has been too strong to be endured. Huntington argues that the wave of democratization can be traced by the birth of groups in the transition from non-democratic regimes to the democratic government, which occur within a specified period of time and that significantly outnumber transition in the opposite direction during that period of time. Huntington's democratization can be analyzed from several things, for instance the making of a space for press freedom, social movements that are increasingly free to show their existence, an increasingly democratic electoral system, rights to gather and associate that have guaranteed by the constitution in various ways, ideology and belief (except communism). As a result, all these organizations, associations and unions suddenly present in large numbers as a new vehicle for civil society.

Unexpectedly, democratization is not merely advantage the nationalist ideology who accepts Pancasila as a state ideology. Some Islamic associations that have been genealogically rooted in Islamist groups in the past (such as DI / NII) also developed amid the euphoria of democracy that occurred in Indonesia. Some of groups want to purify and enforce Islamic sharia as a single basic principle of the state, including in combating injustice, arbitrariness and other immoral behavior such as gambling, drunkenness and adultery. For instance, the establishment of the Islamic Defenders Front (FPI, Front Pembela Islam) that desires to make 
an Islamic Sharia as a reference in eradicating disobedience of Islamic norms. In Solo, several movements emerged to establish their identity as a group that wants to fight for Islamic politics. The numbers of local Islamic vigilante groups which have ideology to realize political Islam appeared such as Laskar Jundullah which is the wing of the Forum Komunikasi Aktifis Masjid (FKAM, Mosque Activist Communication Forum, 1999), Laskar Hizbullah (1999), Surakarta Islamic Youth Front (FPIS, 1999), Tim Hisbah and Laskar Umat Islam Surakarta (LUIS, Islamic vigilante group of Surakarta 2000). The last two movements; Tim Hisbah and LUIS are the keywords in this paper. Most of the local Islamic vigilante groups in Solo have now merged into one group; Laskar Umat Islam Surakarta. They tried to consolidate power through massive movements. Meanwhile, Tim Hisbah has lost a key figure after the leader Sigit Qordhowi had shot by Detasemen Khusus 88 Anti Teror Polri (Special Detachment 88 anti-terror). Organizationally, Tim Hisbah is not a movement anymore, but ideologically they remain in one command in against on, what they consider as thagut.

Forum Komunikasi Aktifis Masjid (FKAM, Mosque Activist Communication Forum) is one of local Islamic mass organization in Solo which formed in the middle of the tumultuous political crisis and reformation demanding in 1998. This forum was organized by several activists of Al-Amin Mosque at Laweyan, Surakarta. The organization's forum actively campaigns against issues that they consider being harmful to Muslims; such as the US military invasion of Afghanistan and Iraq, terrorism framing by mass media, and campaigning for liberation of Muslim oppression during the New Order. The members of FKAM also claim that they have taken part in overthrowing The New Order authoritarian regime. Like other Islamic mass organizations, FKAM has a security task force or wing of paramilitary organizations which they call Laskar Jundullah. In addition to FKAM, the other Islamic vigilante group is Laskar Hizbullah. Laskar Hizbullah actually does not a local Islamist 
movement in Solo, because this vigilante group is organizationally a paramilitary unit of the Partai Bulan Bintang (PBB, Crescent Star Party) which was established in 1998. However, the Laskar Hizbullah in the Solo city is very active in anti-immoral acts and voiced the application of the Islamic sharia in Indonesia, at least through the sharia by law. This activity has made the distinction between the Laskar Hizbullah in Solo and other one outside Solo. As a task force unit of political parties, Laskar Hizbullah is also actively campaigning for the victory of the Partai Bulan Bintang in the 1999 elections.

Another local Islamist movement is the Front Pemuda Islam Surakarta (FPIS, Muslim Youth Front of Surakarta). Front Pemuda Islam Surakarta was formed in 1999 by several people who had basically been members of the Pengajian Gumuk (Jama'ah Gumuk). This movement was born with the same triggers as Laskar Jihad; the problem of the Ambon conflict. But, they did not directly engage in institutional involvement to Ambon. In the following years, FPIS became a movement which, according to them was an anti-immoral movement, besides that they also responded to national and international political issues which claimed tendentiously harmful to Muslim people like the worlds vigorous policy to fight terrorism. Nevertheless, in its movement history, FPIS has little bit tension with some other local Islamist movements in Solo. The tension occurred because the spiritual journey of Mudzakkir, the leader of Jamaab Gumuk, who had studied Islam in several places that were allegedly the center of Shia movements such as in Iran and the Yayasan Pesantren Islam (YAPI, Islamic Boarding School Foundation) in Bangil, East Java (Wildan, 2008).

Having passed a decade after the fall of the New Order, some of the local Islamist movements seem disappeared. Instead, some of the members merged into the Laskar Umat Islam Surakarta (LUIS, Muslim Vigilante Group of Surakarta). Laskar Umat Islam Surakarta has a more universal name than the names of other local Islamist movements in Solo. 
Initially, this group was formed because of the response to the situation of Muslims in the Poso civil conflict in 2000. Some people representing Islamic organizations in Solo held a meeting at the Sriyadi's home, Pajang, Solo. Sriyadi is one of the sympathizers of Islamist group in Solo. The result of that meeting compels to form an alliance group of several Islamic organizations that were ready to carry out Muslim solidarity actions regarding the bloody tragedy of Ambon in the city of Solo. Finally, the Laskar Umat Islam Surakarta declared with ten main initiators of the organization's establishment from several mass Islamic Organization around Solo: Edi Lukito, Salman al-Farisi, Hendro Sudarsono (Laskar Mujahidin), Jayendra Dewa, Yusuf Suparna, Muhammad Kalono (Laskar Jundullah), Yani Rahmanto (Hisbullah), Khairul (FPIS), Heru Prayetno (Satuan Tugas Keamanan Majelis Tafsir Al-Quran, security task force MTA) and Sriyadi (Komando Kesiapsiagaan Angkatan Muda Muhammadiyah, KOKAM, Resilience Command of the Muhammadiyah Youth). The meeting also scheduled Islamic mass rallying to respond to the Ambon case that had not yet ended. On December $16^{\text {th }}, 2000$, several Islamic mass organizations were mobilized to fill the Solo West City Stadium to carry out Muslim solidarity. At that time, LUIS was declared as an alliance of all elements of the Muslim organization; the declaration was also witnessed by the head of Majelis Ulama Indonesia (Indonesian Ulama Council) in Solo.

\section{How Islamism Works}

Several theories reveal that Islamism works as a strict ideological framework. As the most important element in Islamic activism, ideology has a central role that has the power to foster enthusiasm among Muslims to act. Moreover, the ideology of Islamist is usually wrapped in the sacredness of the texts; Al-Quran and hadits that make the faithful willing to do anything in order to get the high piety degree according to their 
teachings. Theoretically, ideology means as an idea, belief or value that become the basis for the representation of the group identity. Ideology becomes a guide and foundation on whether an action is good or bad, right or wrong, and obligation or prohibition for an individual or group. Ideology may also influences what is accepted as true or false, especially when such beliefs are found to be relevant for the group. But in some cases ideology is not simply a "world view" of a group, but rather the principles that form the basis of such belief. It can be also is a function the material and symbolic interest of the group. (Van Dijk, 2000) according to the theoretical framework of ideology, there are three important elements in an ideology. First, the ideology would tell what is true or false. Second, the ideology may become the handbook for problem solving. Third, the ideology is also discussing about the way of implementation and dissemination a group principle, in order to gain the common interest.

In relation to social movements and political Islam, ideology is no less important than the process of framing, because ideology could convey more complex and deeper meanings. The ideology can capture actors' beliefs and ideas in other way. Meanwhile, as a discourse, action and movement, Islamist movements are often described as religiousideological symptoms. However, it can be denied, that Islamism also born from a certain idea and view of the world order based on religious doctrines and beliefs (Hasan, 2012). Coclanis and Bruchey remind, that researchers have to know how the ideology is translated by a social movement into the action program, which will lead researchers to the questions about the process of framing, trajectory, strategy and tactics (Coclanis \& Bruchey, 1999).

The doctrinal foundation of Islamist ideology is a sacred and uncompromising belief; Tauhid. Tauhid is the most important thing that must be strengthened and confirmed by a Muslim in any condition. Islamists always take the example of the Prophet's history which first 
changed the "concept of god" of his companions before teaching the sharia. This robustness of taubid is believed by the Islamists to make the companions of the Prophet Muhammad willing to emigrate (bijrah) and strive for the political interests of the Muslims in Medina. It could be simplified that the two cores of the Islamist ideology are tubid and bijrah. After taubid, hijrah is an unavoidable consequence. The concept of the most popular hijrah according to Islamists is the spiritual journey to the true piety. In other word, the goal of hijrah is that someone have to be a people who separate his self from the part of their past which is considered as jabiliyah period. Obviously, the concept of bijrah is often contextualized into political attitudes that demand the Islamization of the socio-political system of the state.

The exploration of Islamist movement through the ideological perspective is elaborated less. The further question is; what drives someone to be an extremely Islamist? Moreover, some Islamists are willing to make terror or radical actions. Is the answer just because the ideology? Avoiding the simplification answer, Tinka Veldhuis and Jorgen Staun explain by using root cause model. Root cause model started by defining the two measurement level; macro and micro level. This analysis model argues that macro-level are preconditions for radicalization. For explaining why some people could be an extremely Islamist, and why other people do not do so, this model scrutiny of micro-level variables. After having defining the macro and micro-level, the next step is differentiate between "causes", which set the foundation for radical Islamist, and "catalysts", which suddenly accelerate the process of being extremely Islamist. The "causes" may about political, economic, and cultural conditions, and catalyst could be seen from the trigger events. The discussion in this "cause" factors is about how Islamists interpret these political, economic or cultural conditions and how they response to these situations. Further, the micro level categorized into social and individual factors. Social factors are 
represented by the social identity, relative deprivation, social interaction and group processes. The individual factors are represented by personal characteristic and personal experiences.

Thus, the ideology of Islamist present in relation to macro and micro conditions of social-political circumstances. The Islamist movement born in pre-independence certainly had ideas, motivations and strategies that were different from the Islamist movement at the beginning of independence, the New Order era and in the Reformasi era. As the Quran which the teachings are applied by people across the ages, so that the practice of Muslim society towards the Quran altered from the past 14 centuries ago with the present days. Islamism is certainly has its own context that is also constantly changing. Islamism which was formerly theorized as a strict ideology that has desire in islamizing every single of life to be derived from Islamic values, now become acculturated with other ideologies. Islamism is in the trend of changes. Asef Bayat calls this trend of change in Islamism by the term post-Islamism. Islamism is seen as a scientific projection and a new trend in Islamic social movements in modern Muslim countries such as Iran, Turkey, Morocco, Egypt and Indonesia. Islamism has a trend of transformation in a more democratic direction, describing a condition with characteristics of unification of religion and modern freedom (Bayat, 2007, 2013).

Some scholars argue that Islamism currently works by following the latest trends in the development of global socio-political conditions. The keyword "Most votes, the most support" is one of the logics of democracy used by Islamists as a strategy for gaining broader public support for the ideology of Islamism. The Delivery of narration and Islamism discourses is appropriated to the national interests such as corruption eradication, human rights, justice, and legal certainty (Ahyar, 2017). The discursive strategy exhaled using the latest technological devices and mode of digital information. Some Islamists demurely overspread their Islamism 
ideological propaganda via-online social media and online messenger like Facebook, Instagram, Youtube, Twitter, WhatsApp and Telegram. The ideology of Islamist in Indonesia has quite adapted enough to the modern political system; democracy.

\section{Reproliferation of Islamism in Contemporary Surakarta}

Initially, the Islamist movement in Solo is not directly involved with contemporary Islamist movements like Islamic State. The reference actors of previous Islamists in Indonesia were Abdullah Sunkar and Abu Bakar Ba'asyir. Abu Bakar Ba'asyir has an extensive network with Islamist colleagues outside Indonesia. Similar to al-Zarqawi, Abu Bakar Ba'asyir was a former combatant who had trained in Afghanistan in the 1980s. Because of its network with other combatants in Afghanistan, Abdullah Sunkar and Abu Bakar Ba'asyir became the political fugitive of the New Order government. His status as a political fugitive made him move to Malaysia to avoid the Indonesian government. In the first years of Reformation era, Ba'asyir becomes the single prominent figure after the dead of Sungkar.

After the dead of Abdullah Sungkar, contemporary Islamist figure was Aman Abdurrahman. Ba'asyir and Aman have the strong influence in making the Islamist thought and behavior among some Muslims in Surakarta. Al-Mukmin Ngruki Islamic boarding school (which initiated by Ba'asyir) remains the allure for some people's argument about Ba'asyir's struggle to promote and fight for Islam through the educational field. As for Aman Abdurrahman, he was much attention by other Islamists because of his consistency in fighting for Islam through the radical Islamism ideology which oppose the muslim country which has no implementation of Islamic sharia. Moreover, after the court decision which has decided that Aman had to serve a death sentence. Aman seems to be the hero in other Islamists perspective. The two famous figures of disseminator

DINIKA, Volume 4, Number 2, May - August 2019 
of Islamism have their own followers and strategy. Aman deemed to be consistently opposed the secular states which, according to him, Indonesia is one of it. Nevertheless, Aman was not the combatant as his Islamist senior; Abu Bakar Ba'asyir, so he is inexperienced in battlefield of jihad. Aman also has not network as broad as Ba'asyir. Abu Bakar Ba'asyir and Aman Abdurrahman have different manhaj and thariqah in fighting for Islamism in Indonesia. Just like the strategy of Islamic State, Aman is a stubborn person in his effort to establish an Islamic state and he did not compromise in any way other than changing the system radically. On the other hand, Abu Bakar Ba'asyir has a numbers of experiences that make him astute as a bearer of the ideology of Islamism. Indeed, some movement he formed as his endeavor to spread out the Islamism spirit in any form. In the New Order Period, Ba'asyir walks with Islamism through the Darul Islam movement and Jamaah Islamiyah; the Islamist wings in Southeast Asia. After the collapse of the authoritarian regime, Ba'asyir was one of the figures who initiated the birth of the Indonesian Mujahidin Council organization and the Jamaah Ansharut Tauhid.

Although the strategy of the Islamists is different in fighting for the establishment of Islam as a technical rule in regulating the country, they have the same initial step. The main step in Islamist thinking about the Islamic tradition is building a new understanding of Islam as "din wa daulab"; the merging of religion and state interest. Islamism places the unity of religion and state almost on the same basis as syabadat (Islamic confession) as an indicator of how high a person's religious values. Therefore, the main indicator to know the characteristic of Islamist is the argument that Islam is a permanent and final state order. Some Islamist movements in Solo have similar characteristic with the Islamist main indicator.

International Islamist movements such as Al-Qaeda, Jamaah Islamiyah and Islamic State in Iraq and Syria also play an important role in the development of Islamist movements in Solo. The proliferation of 
al-Qaeda into Islamic State in Iraq and Syria, although indirectly, has also affected the proliferation of Islamism in Indonesia. After Osama bin Laden, the founder of al-Qaeda, was reportedly died by American authorities, alQaeda's leadership turned to Ayman Al-Zawahiri, an Egyptian Islamist who has many followers in various other Arab countries. Because of the large number of networks formed, Al-Qaeda is no longer the only one who is loudly showing the hostility to Western countries; Abu Musab Zarqawi, one of Ayman's followers, appeared with enthusiasm against America. Zarqawi is one of the combatants of al-Qaeda in Iraq who later joined the Majlis Syura al-Mujabidin fil Iraq (Mujahideen Shura Council). This symbol of warfare was conveyed visually to the decapitation of Nicholas Berg, one of the American radio-tower repairman. The decapitation was welcomed by other Islamists because of the radical response of the Abu Musab al-Zarqawi group to the American government. In the further era, one of the students of al-Zarqawi; Abu Bakar Al-Baghdadi appeared on the stage of Islamism through the movement of Islamic State in Iraq and Syria (ISIS). In 2014, Abu Bakar Al-Baghdadi delivers his speech which essentially called on Islamists to fight their own countries, especially Syria and Iraq. He argues that Syiria is not for Syirians and Iraq not for Iraqis. This speech heralded the end of ISIS and the birth of the Islamic State. The strategy changes from Syirian and Iraq battlefield to the indiscriminate attacks in several countries (Weiss \& Hassan, 2016). The current political condition in Syria make Islamic State a common enemy. The Opposition movements such as Jabhat an-Nushra, abrar ash-syam and so forth also withdrew their support from Islamic State as an Islamist movement that opposed to government. The Islamic State is the only movement that is still loud in voicing its ambition to co-opt the state in order to uphold an Islamic state. The case of Islamist movements in Syria such as al-Jaisy as-Suri al-Hurr (Free Syirian Army), Jabhat an-Nushra and Quwwat Suriya AdDimuqratiyah (Syrian Democratic Forces) describe the strategy of Islamist 
supporters of the Caliphate which "on coming" toward the logic of "nation-state", even though as a government opposition party. The cases of the proliferation of radical Islamist movements in Syiria also show that Islamist movements are plural in echoing the discourse of the Islamism ideology and interpreting the revival of Islamic caliphate in Islam.

The condition of Islamism in the context of international politics is also occurring in Solo. Today, the sympathizer of Islamist ideology in Islamic State's version becomes a minority that stands on a small group. The conditions of proliferation of the international Islamist movements such as Al-Qaeda and Islamic State also influenced the proliferation of the Islamist movement in Solo in the contemporary era. The proliferation of earlier Islamist which presents some Islamist groups in Reformasi era, like FKAM, Tim Hisbah, FPIS, and Laskar Jundullah, do not continue their existence anymore. So far, the bearer of extreme Islamist ideology (like Islamic State) widely expressed by the former members of Tim Hisbah group. Tim Hisbah is one of Islamist groups in Solo that was led by Sigit Qordhowi. Sigit is suspected involving several legal cases related to radicalism and terrorism.

In the middle of 2011, Sigit was shot dead in the national operation of combating terrorism by the Detasemen Khusus 88 Anti-Teror Polri (Special Detachment 88 Anti-Terror the Police of Indonesia). The death of Sigit was changed the future trajectory plan of Tim Hisbah. Organizationally, Tim Hisbah has disappeared following the death of the leader; Sigit Qordhowi. But, the ideology of Islamist is still embedded radically in the members' heart of Tim Hisbah. Organizational leadership turned to Agus Junaidi, Sigit's comrade who was also respected by other members of Tim Hisbah. Agus has a more "soft" strategy than his senior, Sigit. Agus often has been consulting with the army (TNI) and police through the forces of public services; Babinsa (Bintara Pembina Desa) and Babinkamtibmas (Bayangkara Pembina Keamanan dan Ketertiban Masyarakat), dealing with the 
so-called social disease in Indonesia like gambling, liquor, drugs and thuggery. Except the endavour in propagating the ideology of Islamism, Tim Hisbah also often conducts private raid for social behavior that is considered to violate the religious law. Through the former members of Tim Hisbah, the ideology of Islamist (in Islamic State version) has been propagating to a broader people in Solo. Nowadays, some of them try to propagate the Jama'ah Ansharud Daulah, an Islamist group that supports the Islamic State ideology.

The current dominant Islamist voice holder in Solo is in LUIS. Despite it has spirit of Islamism, LUIS has becomes a post-Islamist movement that does not demand explicitly the establishment of an Islamic state in Indonesia. As a community organization that is currently has a legal entity, LUIS is a civil society organization with a post-Islamist ideology as well as other social organizations. The network of LUIS organization currently spreads in several cities in Central Java and has diverse backgrounds; students, lecturers, advocates, NGOs members, traders and so on. Laskar Umat Islam Surakarta actively propagates the Islamist ideology by voicing some discourses regarding Muslim interest in Indonesia with some affiliated groups. Indeed ideologically, LUIS does not support the Islamism strategy championed by the Islamic State, the members of LUIS realize that Indonesia is a peaceful homeland and national shared house; thus Indonesia have to be kept so as does not become a battlefield of jihad. Although it is contrary to the strategy of the Islamic state in campaigning for Islamism, LUIS longed for the Indonesian government to run under the rule of Islamic law. Therefore, they always have been trying to realize the discourse of Islamism through the establishment of sharia by-law such as the anti-liquor regulation.

In voicing Islamism discourse on a wide scale, several Islamist organizations in Solo were under the command of the Dewan Syariah Kota Solo, (DSKS, Sharia Council of Solo) under the leadership of Muhammad 
Muindinillah Basri, a senior lecturer from the Muhammadiyah University of Surakarta, one of the leading universities in Solo. While LUIS organizes various Islamic armies in Solo, DSKS has been focusing as an ideological function for several Islamist groups in Solo. For some Islamists, DSKS is an authoritative institution that has most authority to determine the strategy of the Islamists in propagating for Islamic sharia as a shared value in Indonesia. Dewan Syariah Kota Solo synergize with the Solo Majelis Ulama Indonesia (MUI, Indonesia Ulama Council) in controlling the dynamic of Muslim religiosity in Solo. Dewan Syariah Kota Solo also actively in action of legal advocating for members of the Islamist groups in Solo who are allegedly involved in legal cases, especially relating to radicalism and terrorism cases. Besides, DSKS has been a frontline in overseeing cases considered as religious blasphemy cases to Islam. Therefore, DSKS is a trigger for the community's enthusiasm in supporting every Aksi Bela Islam (Defending Islam action) which has been a massive action of several Muslim communities in Indonesia since two years ago.

Some Islamic organizations in Solo try to resonate and disseminate the discourse of Islamism by utilizing the latest technological developments and information. The media became the primary tool for Islamist groups in Solo in spreading some relating issues. One of the most influential media is Panjimas.com, an online media run by several Islamist activists in Solo. While some News and issues were published in the media, Islamists quoted and distributed through several social media (Facebook, Twitter, Instagram) and online short messages sender (Whatsapp, Line, Telegram and so forth). Islamists always use the media to raise the good opinion in the wider community that Islamist groups in Solo really want to develop Indonesia through Islamic values. For this reason, the discourse disseminated through the media has always appropriated with the national interests of the Indonesian nation such as corruption eradication, justice, welfare, supremacy of law and human right (Ahyar, 2017). 


\section{Conclusion}

The earlier proliferation of Islamist movements in Solo left a deep spirit of Islamism, to the current Islamist groups in Solo. Organizationally, Islamist in Solo formed in several groups. The various groups of Islamist are shaded by the tansiq organization (alliance); Laskar Umat Islam Surakarta, which is an alliance of Islamist militants in Solo. Ideologically, the proliferation of Islamist movements in Solo is inherited by the ideological spirit of its predecessor movements such as Darul Islam, Jamaah Islamiyah, and Jamaah Ansharut Taubid. The role of the earlier Islamist movements illustrate that the spirit of Islamism is still firmly rooted for some people. The reproliferation of Islamist movement occurred due to several factors; among of them are the condition of international Islamist movements, the influence of prominent ideological figures and the current democratization that continuously developed in Indonesia. Because of the Islamic State ideology today is widely opposed by many other Islamist movements all over the Islamic worlds. It makes the affiliated movement in Indonesia less consolidation and lack of support from the international Islamist movements. Radical Islamist movement, which has an uncompromising principle to establish an Islamic state in Solo, currently becomes an unshared ideology among other Islamist movements. They are gathered in small organizations which are also widely opposed by other post-Islamist groups. The spirit of Islamism, which born from the milieu of democracy in Indonesia, compels Islamists to advantage the logic of democracy in gaining the broader sympathy from Indonesian people. Advantaging the democratic condition in Indonesia, reproliferation is continuously occurring. Some Islamist movements focus on the movement strategy which appropriated to the national interest of Indonesia. The Islamism discursive strategy then becomes easily delivered to the society by utilizing the latest technological devices. The effort of this strategy is to merge between the political activism in the "real" world and in the cyber space. 


\section{References}

Abas, N. (2009). Membongkar jamaah Islamiyah: pengakuan mantan ketua JI. Abdika Press.

Ahyar, M. (2017). Islamic Clicktivism: Internet, Democracy and Contemporary Islamist Activism in Surakarta. Studia Islamika, vol 24(3), 435-468. https://doi.org/10.15408/sdi.v24i3.4859

Anshori, A. Y., Yusuf, E., \& Zarkasyi, F. (2008). Untuk negara Islam Indonesia: perjuangan Darul Islam dan al-Jama'ah al-Islamiyah. Siyasat Press.

Ayubi, N. (2003). Political Islam: Religion and Politics in the Arab World. Routledge.

Bayat, A. (2007). Making Islam Democratic: Social Movements and the PostIslamist Turn. Stanford University Press.

Bayat, A. (2013). Post-Islamism: The Changing Faces of Political Islam. OUP USA.

Coclanis, P. A., \& Bruchey, S. (1999). Introduction. In Ideas, Ideologies and Social Movements, The United States Experience Since 1800. Columbia: University of South Carolina Press.

Hasan, N. (2012). Islam Politik di Dunia Kontemporer: Konsep Geneologi dan Teori. Yogyakarta: Suka Press.

International Crisis Group (ICG). (2005). Recycling Militants in Indonesia, Darul Islam and Australian Embassy Bombing (Asia Report).

Kepel, G. (2006). Jihad: The Trail of Political Islam. I.B.Tauris.

Nasihin. (2012). Sarekat Islam mencari ideologi, 1924-1945. Pustaka Pelajar.

Qodir, Z. (2003). Ada apa dengan Pondok Pesantren Ngruki. Pondok Edukasi.

Roy, O. (1996). The Failure of Political Islam. Harvard University Press.

Solahudin. (2011). NII sampai JI: salafy jihadisme di Indonesia. Komunitas Bambu.

Tibi, B. (2012). Islamism and Islam. Yale University Press.

Van Dijk, T. A. (2000). Ideology, Multidisciplinary approach. London: Sage Publication.Ltd. 
Weiss, M., \& Hassan, H. (2016). ISIS: Inside the Army of Terror (Updated Edition). Simon and Schuster.

Wildan, M. (2008). Mapping Radical Islamism in Solo: A Study of Proliferation of Radical Islamism in Central Java, Indonesia. AlJami'ab: Journal of Islamic Studies, 46(1), 35-69. 